\title{
Erratum: The essential role of charge-shift bonding in hypervalent prototype $\mathrm{XeF}_{2}$
}

Benoît Braïda and Philippe C. Hiberty

Nature Chemistry 5, 417-422 (2013); published online 7 April 2013; corrected after print 9 October 2015.

This Article was accepted on 28 February 2013. This information appeared incorrectly in the original versions of this Article and has now been corrected in the online versions. 